borough and at Bedford. The late Dr. G. P. Douglas led the Aerodynamics Department for many years, and, upon his retirement in 1953, Mr. Nicholson was appointed as his successor.

\section{The Electricity Bill}

The debate in the House of Commons on December 17 on the second reading of the Electricity Bill had several features of scientific and technical interest, quite apart from its importance in relation to the generation and distribution of electricity, particularly of that generated by nuclear power stations. Further tributes were paid to the achievements of scientists and engineers at Calder Hall and elsewhere, but the debate centred largely around the Herbert Report, which had not previously been discussed in the House. Particular attention was directed to the question of research and to the importance of management and the human factor. Mr. J. Callaghan had expressed some concern as to the co-ordination of research, and Mr. Albu also had emphasized the importance of such co-ordination in relation to the large-scale research on storage, heating, etc., which is required.

In reply, the Parliamentary Secretary to the Ministry of Fuel and Power, Mr. D. Renton, said that while the area boards will carry on their own research, the results will be pooled with the Electricity Council, which would also conduct research on its own behalf. He did not, however, meet the specific criticisms of the Herbert Committee as to the volume of research. More specific attention was directed to the question of management, particularly to the importance of attracting $a$ sufficient proportion of the ablest administrators and technologists. In regard to this, the Herbert Com. mittee was highly critical and its recommendations found general support. The Minister, in opening the debate, had said that, while the Government is giving serious thought to the matter and appreciates the force of the comments made both by the Fleck Committee and the Herbert Committee, it is unable to act on the recommendations regarding the dis. parity of rewards for those at the head of a nationalized industry compared with those in corresponding positions in private industry; nor did Mr. Renton add to this in replying on the debate. Mr. C. R. Hobson pressed the necessity for staff training and of providing avenues for promotion to the top for suitable talent from all levels, while the importance of attention to the appointment, selection and promotion for the lower managerial posts was stressed by several speakers, Sir Keith Joseph pointing out also that the failure to pay high enough salaries at the top levels of management adversely affected, as the Herbert Report emphasized, the position of the middle management and technical staff. It was clear that the House was not satisfied that adequate steps have been taken to deal with a matter which determines the efficiency of the management of the whole industry. This point was firmly made by $\mathrm{Mr}$. Geoffrey Lloyd, who incidentally paid a tribute to the value of the research carried out on a boiler plant to consume low-grade fuel, as well as by other speakers, and the debate established that the recommendations of the Herbert Committee are largely accepted by Parliament, independently of party lines. Mr. Albu stressed the value of joint consultation at all levels, and the importance of the human factor, not only in management but also throughout the industry, is fully appreciated.

\section{Scientific and Technological Education}

THE "Rationalist Annual" for 1956 (pp. 96. C. A. Watts and Co., Ltd.; 3s. 6d.) includes a forthright article, "The Chaos in Scientific Recruitment", by Prof. H. Levy, criticizing the methods hitherto adopted to increase the supply of scientists. The acute shortage of science teachers is only one aspect of a shortage which has caught both Government and industry unawares. Not only is the Atomic Energy Authority without more than one-tenth of the scientists it needs on its staff to direct research groups of a dozen or more juniors, but also in 1955 the Services recruited less than half the graduate scientists, especially those with degrees in engineering, physics and mathematics, which they required. Prof. Levy stresses the importance of removing barriers to the fullest exchange between industry, industrial research and practice and so-called academic isolation, and that the fundamental need is to review the whole educational system, from five to twenty-five, to ensure that at each stage facilities exist for bringing out the full potential energy of the whole population and encouraging its interest in directions that are most desirable socially. The prospective 'bulge' in the number of senior pupils or university students was an opportunity for which we should have been preparing during the past ten years, and Prof. Levy remarks that while normal academic procedure provides for the passage from theory to practice, society has not yet provided for the equally important transition from practice to theory. This, he suggests, is largely the business of industry, the research laboratories of which could provide the basic structure for such developments if they extended their scope by the provision of instructional laboratories and, where possible, used personnel engaged on research. Lord Chorley contributes an article on "Freedom of Discussion To-day", dealing more particularly with the question of libel and with the guidance which American experience offers Britain.

\section{International Exchange of Students}

THE ninth annual report of the International Association for the Exchange of Students for Technical Experience records another increase of 558 in the number of students exchanged, the 5,711 exchanged in 1956 bringing the grand total to 28,668 . Germany $(1,284)$, Great Britain (743), Austria (637), the Netherlands (417), Sweden (415) and France (367) sent the most students, and Sweden $(1,305)$, Germany (1,019), Great Britain (774), the Netherlands (354), Austria (337), France (336) and Finland (304) received the greatest numbers. There was a large increase in the exchange between the United States and other countries (131 compared with 59 in 1956) and also in the exchanges of Canada, the Netherlands, Spain and Turkey. The Union of South Africa joined the organization as an associate member in January 1956. The annual conference was held at Trondheim, January 16-20, 1956, when the Advisory Committee was asked to examine the possibility of improving training programmes in industry and also to investigate the possibility of establishing a fund to assist necessitous students with their travel expenses. In some countries students participating in the exchange already have the advantage of reduced railway fares, and considerable progress has been made in the exemption from income tax of payments to students by the establishment of reciprocal agreements between certain Foreign Offices. Mr. R. A. Beijer, Svenska Industrins Praktiknämnd, 